\title{
Religious pluralism in practice: Defining secularism in Kenya's headscarf cases
}

\author{
Mukami Wangai*
}

Present day Kenyan society represents a plurality of peoples, ideas and consequently, approaches to life, a state well embodied in the Constitution of Kenya, 2010 (2010 Constitution). ${ }^{1}$ The apparent diversity presents challenges to the preservation of the multi-coloured nature of the society and at the same time guaranteeing rights and freedoms as envisaged by the 2010 Constitution. The preamble to the 2010 Constitution reconciles the two interests by celebrating the 'ethnic, cultural and religious diversity' of Kenya and envisioning an existence 'in peace and unity as one indivisible sovereign nation'. ${ }^{2}$

A marriage of diversity and peaceful coexistence requires tolerance in order to balance competing rights. Within Kenya's plural society, the most visible religion freedom disputes have been between the Christian majority and Muslim minority. ${ }^{3}$ Present constitutional clashes between the two religions date back to the Constitution of Kenya, 1963 (Independence Constitution) ${ }^{4}$ and its 1969 revision (Repealed Constitution), ${ }^{5}$ which granted Kadhis' courts limited jurisdiction within a 10-mile coastal strip of the country. ${ }^{6}$ Following heated debate on matters of religious pluralism during the constitutional review process, ${ }^{7}$ the 2010 Constitution introduced a more accommodative framework for religious freedom. ${ }^{8}$

Constitution of Kenya (2010).

Preamble, Constitution of Kenya (2010).

Green MC, 'Religious and legal pluralism in recent African constitutional reform', 28 Journal of Law and Religion, 2013, 404.

Constitution of Kenya (1963).

Section 66, Constitutional of Kenya (1969).

Green, 'Religious and legal pluralism in recent African constitutional reform', 407-408.

See Cussac A, 'Muslims and politics in Kenya: The issue of the Kadhis' courts in the constitutional review process', 28 Journal of Muslim Minority Affairs (2008).

8 Green MC, 'Religious and legal pluralism in recent African constitutional reform', 410.

* $\quad$ BA (SOAS), LLM (Duke) 


\section{Framework for religious freedom}

The right to freedom of religion and belief is guaranteed under the 2010 Constitution.' Article 32 guarantees 'every person the right to freedom of conscience, religion, thought, belief and opinion' and the right 'to manifest any religion or belief through worship, practice, teaching or observance'. ${ }^{10}$ Article 32 also protects every person from denial of access to an institution, employment or facility on the basis of belief or religion. ${ }^{11}$

The Article 32 right to freedom of religion and belief is buttressed by Article 27's guarantee of equality and freedom from discrimination as well as Article 24's protection against limitation of rights except where permitted by law and to an extent that is proportionate. Under Article 21, the 2010 Constitution further protects the needs of vulnerable religious communities. ${ }^{12}$

Interestingly, the extensive protections afforded to the right to freedom of religion and belief are within the context of Article 8's declaration that 'there shall be no State religion'. ${ }^{13}$ The separation of religion and State in the 2010 Constitution points to a secular State, thus an expectation of neutrality in view of various and differing religions and beliefs. This is drawn from the Article 8 provision that does not establish an official religion, leaving State legislative and judicial processes outside of religious control together with recognition of religious freedom. ${ }^{14}$ Nevertheless, in practice, religion continues to have a noticeable influence on State affairs and public policy. ${ }^{15}$

\section{Secularism and school policies toward religious dress}

Deliberations on the extent and meaning of secularism in the Kenyan context and the extent of permissible manifestations of religion have prominently played out in cases involving wearing of religious dress, particularly headscarves, in public education. As a clear visible manifestation of multiple faiths, ${ }^{16}$ most

\footnotetext{
9 Constitution of Kenya (2010).

10 Article 32(1) and (2), Constitution of Kenya (2010).

11 Article 32(3), Constitution of Kenya (2010).

12 Article 21, Constitution of Kenya (2010).

13 Article 8, Constitution of Kenya (2010).

14 Kuru AT, Secularism and state policies toward religion, the United States, France, and Turkey, Cambridge University Press, Cambridge, 2009, 7.

15 Hassan AI, 'The constitutional management of religious diversity in Kenya', Regional Conference on Constitutional Democracy in Africa, Nairobi, 19-22 August 2008.

16 See, for example, a challenge by the Arata Arobo Mutheru Society ('Kavonokya') in Ndanu Mutambuki \& 119 Others v Minister for Education \& 12 Others [2007] eKLR.
} 
predominantly Islam, Kenyan courts have been asked to determine whether a religious headscarf is to be permitted, or accommodated, in school uniform policies. The twin cases of Republic $v$ The Head Teacher, Kenya High School \& Another Ex - parte SMY $Y^{17}$ and Mohamed Fugicha v Methodist Church in Kenya \& 3 others ${ }^{18}$ present two opposing interpretations on the meaning of secularism in Kenya, with the earlier case permitting the exclusion of the Islamic headscarf in school uniform policies and the later case prescribing its inclusion in the same policies.

Both cases arose out of parental challenges to school uniform policies that did not accommodate Islamic dressing. In the first case, Kenya High, ${ }^{19}$ a student at an all-girls national secondary school wished to wear the hijab to school. At the time the school maintained a school uniform policy that set out a standardised dress code that did not include the hijab. Following complaints to the Departmental Committee on Education, Research and Technology, made in 2009, and forwarded to the Ministry of Education, the Permanent Secretary for Education issued a letter stating that no child should be denied the right to education on the basis of religion and directing principals of schools to re-admit students expelled on the basis of wearing the hijab.

The High Court found no violation of the student's Article 32 right to manifest her religion on the ground that her right was limited within the permissible bounds of Article 24. The school uniform policy met the scrutiny under Article 24 in pursuit of the legitimate aim of promoting social cohesion, discipline, unity and inclusivity with the school's administration acting well within its powers under the Education $A c t^{20}$ and the Education (School Discipline) Regulations in stipulating a standardised uniform. ${ }^{21}$ According to the High Court, the limitation was reasonable and justifiable in order to reconcile the interests and beliefs of the diverse groups represented in the student body of the school. ${ }^{22}$

In the later case, Mohamed Fugicha $v$ Methodist Church in Kenya, ${ }^{23}$ a parent at a mixed secondary school sponsored by the Methodist Church, St Paul's Kiwanjani, wished his children at the school to wear hijabs and white trousers in addition to the standard uniform prescribed in the school's policy. The Court of Appeal

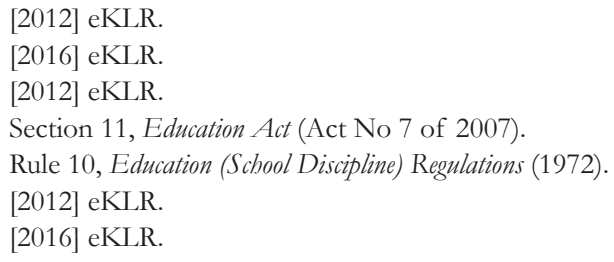


agreed with the High Court's disposition in the Kenya High case ${ }^{24}$ on the necessity of prescribing a standard school uniform to promote unity in diversity. However, the Court of Appeal set aside the initial judgment in Fugicha which applied the Kenya High precedent, disagreeing fundamentally with the High Court justice's approach to the question of discrimination.

The Court of Appeal agreed that the policy was not discriminatory on its face and therefore the Kenya High ${ }^{25}$ assessment was correct in concluding that the policy does not directly discriminate against Muslim students. The Court of Appeal deemed that the issue required a consideration of indirect discrimination. The court found that the absence of an inclusion for Muslim religious dress in the school uniform policy was indirectly discriminatory against Muslim students because compliance with the school policy subjected them to disadvantage of their accepted Muslim religious practice of wearing a headscarf. ${ }^{26}$

The Court of Appeal then turned to consider whether the exclusion of the Muslim headscarf from the school uniform policy is a proportionate means of meeting the non-contentious legitimate aim of social cohesion and inclusivity. The Court of Appeal used the doctrine of accommodation to analyse this question. Applying the approach in the South African case of MEC for Education: Kwazulu-Natal and Others $v$ Pillay, ${ }^{27}$ and describing the school uniform policy in Fugicha as an 'absurd inflexibility', the court found that accommodating the wearing of the Muslim headscarf and white trousers would not unreasonably burden the school and, therefore, it should be permitted. ${ }^{28}$ The Court of Appeal also noted that in failing to give sufficient attention to indirect discrimination and the principle of accommodation in Kenya High, ${ }^{29}$ the High Court took an incorrect doctrinal and normative approach. ${ }^{30}$

Multiple similarities can be drawn between the two school contexts of Kenya High and St Paul's Kiwanjani. Both are well performing schools with students

\footnotetext{
[2012] eKLR.

[2012] eKLR.
}

26 The Court was persuaded primarily by the English case of $\mathrm{R}$ (on the application of Watkins-Singh) $v$ Aberdare Girls' High School \& Anor [2008] EWHC 1865. This position is contrasted from the previous restriction upheld in R (on the application of Begum) $v$ Governors of Denbigh High School [2006] UKHL 15. The court also distinguishes between wearing of a headscarf for a religious purpose and a cosmetic or fashion purpose as was the case in JK (suing on behalf of CK) $v$ Board of Directors of Rusinga School \& Another [2014] eKLR.

[2007] ZACC 21.

[2016] eKLR.

[2012] eKLR.

[2016] eKLR. 
from diverse backgrounds. In addition, the two schools are situated in two widely plural communities, Nairobi County and Isiolo County. In both cases, as is common in schools in Kenya, various accommodations had been made for students of different faiths to enjoy their respective religions and beliefs. Prior to the court cases, the pertinent issue had been discussed at a school level and determinations were made that the status quo in the form of a standardised school uniform policy, without an exception for Muslim students, be maintained.

While neither of these similarities should be determinative on the question of discrimination, the noted points provide an important foray in to what are relevant considerations for courts determining the parameters of the manifestation of religion or belief within the reality of a plural society and self-pronounced secular state. Crucially, the local context should inform the meaning of secularism in each case. ${ }^{31}$ Despite religiously plural contexts in both Kenya High ${ }^{32}$ and Fugicha, ${ }^{33}$ two opposing conclusions were reached by the courts.

From the onset, an immediate parallel can be drawn with Islamic headscarf cases in the European Court of Human Rights (ECtHR). The trio of Dablab v Switzerland, ${ }^{34}$ Sabin $v$ Turkey ${ }^{35}$ and Dogru $v$ France ${ }^{36}$ most clearly typify how a secular identity defines the right to don Muslim headscarves in schools within selfdefined plural but secular societies. ${ }^{37}$ In the three cases, the ECtHR determined that in furtherance of secularism as a democratic ideal, a state is justified in limiting the wearing of an Islamic headscarf as a manifestation of religious freedom.

The type of secularism upheld in Dablab, ${ }^{38}$ Sabin $^{39}$ and Dogrut ${ }^{40}$ squares up to the High Court's position in the Kenya High ${ }^{41}$ case. The decision in Kenya High ${ }^{42}$ prescribes for the country a breed of secularism where the Kenyan State's secular

\footnotetext{
31 Vanderpoel RS, 'Religious equality in Kenya? Adjudicating the constitutionality of Kenya's Kadhis' courts', Regulating Religion E-Journal, 2012, 3.

32 [2012] eKLR.

[2016] eKLR.

Dahlab v Switzerland, ECtHR Judgment of 15 February 2001.

Sabin v Turkey, ECtHR Judgment of 10 November 2005.

Dogru v France, ECtHR Judgment of 4 December 2008.

Calo ZR, 'Pluralism, secularism and the European Court of Human Rights', 26 Journal of Law and Religion, 2010, 264.

Dablab.

Sabin.

Dogru.

[2012] eKLR.

[2012] eKLR.
} 
identity outweighs its plural identity. As in Dablab, ${ }^{43}$ Sabin ${ }^{44}$ and Dogru, ${ }^{45}$ religious freedom is restricted for the sake of maintaining the state's secular identity. ${ }^{46}$

Relying on the 'conventional areas of inquiry into secularism,' it is easy to reconcile the Kenya High ${ }^{47}$ case and the ECtHR headscarf cases above. ${ }^{48}$ To take France and Turkey as two examples, both states are as secular as they come. For Turkey its secularism is as much associated with the official position stated in the State's Constitution that ' $t$ ] he Republic of Turkey is a democratic, secular [laik] and social State...', ${ }^{49}$ as with the nations intended movement away from Islamisation following the establishment of the Turkish State led by Ataturk. In France's case, a long history of secularism culminated in Article 1 of the Constitution of 1958 providing that 'France shall be an indivisible, secular, democratic and social Republic' ${ }^{50}$

Resultantly, as Sabin ${ }^{51}$ and Dogru $u^{52}$ demonstrate, Turkey and France have been restrictive toward Muslim headscarves and, generally, religious symbols in public life. This 'assertive secularism' that 'aims to exclude religion from the public sphere' may suit the contexts of the French and Turkish republics but does not reconcile neatly with the Kenyan one. Without a heavy secularist tone in the country, the Kenya High b3 $^{53}$ ruling appears to go beyond the 'passive secularism', which allows visible symbols of religious life in public, actively lived in Kenya. ${ }^{54}$

\section{A Kenyan conceptualisation of secularism}

The Kenya High ${ }^{55}$ decision is an instance where cited global norms defining secularism as a strict separation between religion and state resulted in a local exclusion for Muslim headscarves. ${ }^{56}$ The same pitfall can be seen in the debate on the presence of Kadhis' courts through the High Court judgment in Jesse

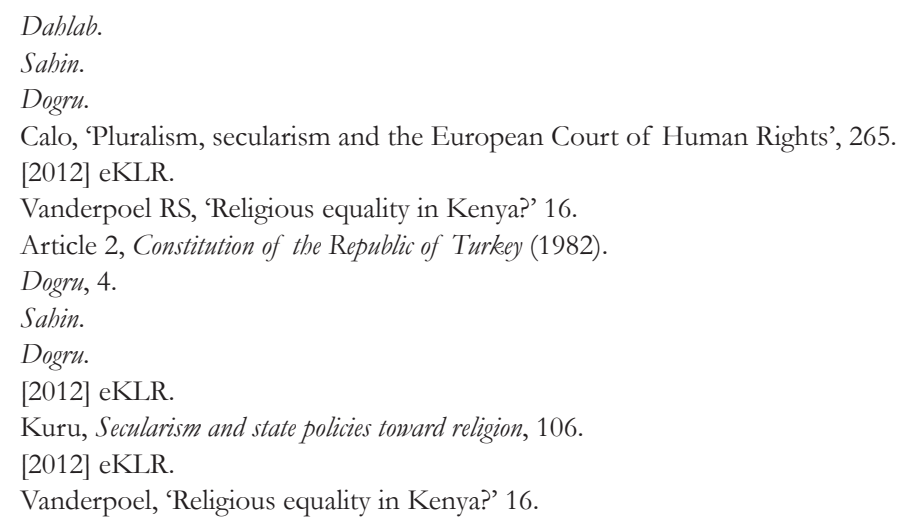


Kamau \& 25 Others v Attorney General. ${ }^{57}$ In defining secularism, the High Court overwhelmingly relied on transnational sources at the expense of 'local conceptualisations of secularism'. ${ }^{58}$ The judgment found the Kadhis' courts an 'unconstitutional violation of Kenyan secularism'. ${ }^{59}$ In a triumph for legal pluralism and religious diversity, the Jesse Kamau ${ }^{60}$ judgment was cancelled out by the 2010 Constitution, which gave constitutional status to the Kadhis' courts. The outcome deflected tensions on the issue between the Christian and Muslim religions. ${ }^{61}$

In Kenya's local context, the reality is a plurality of religious norms where numerous faith communities have been practicing and manifesting their beliefs amongst one another over a long period of time. The disconnect between the Kenya High and Fugicha rulings highlights the need for a broader outlook on what secularism means in Kenya. ${ }^{62}$ A more accurate and fitting definition of secularism can be arrived at by looking beyond traditionally cited secular states such as France, Turkey, and the United States. ${ }^{63}$ Some go as far to say that the three countries are 'exceptional' in their approaches to secularism. ${ }^{64}$ Further, marrying the local context with global perspectives has the potential to explain how present models of secularism are adjusted to appropriately fit domestic settings. ${ }^{65}$

Such an approach appreciates the fact that globally, a variety of views exist as to the meaning of secularism and each state's local context defines the extent of secularism for itself. ${ }^{66}$ Effectively, there exists no single recipe that is universally applicable across each and every situation. ${ }^{67}$ Best seen in the ECtHR model of the 'margin of appreciation' doctrine, a question is raised as to whether within a state, different vicinities can reach different justifiable positions on the extent to which religion can be manifested.

A step past the assertive secularism and passive secularism dichotomy lies a distinction between secularity and secularism. Here, secularity is defined as a form of liberal pluralism, and secularism as a position that is dedicated to main-

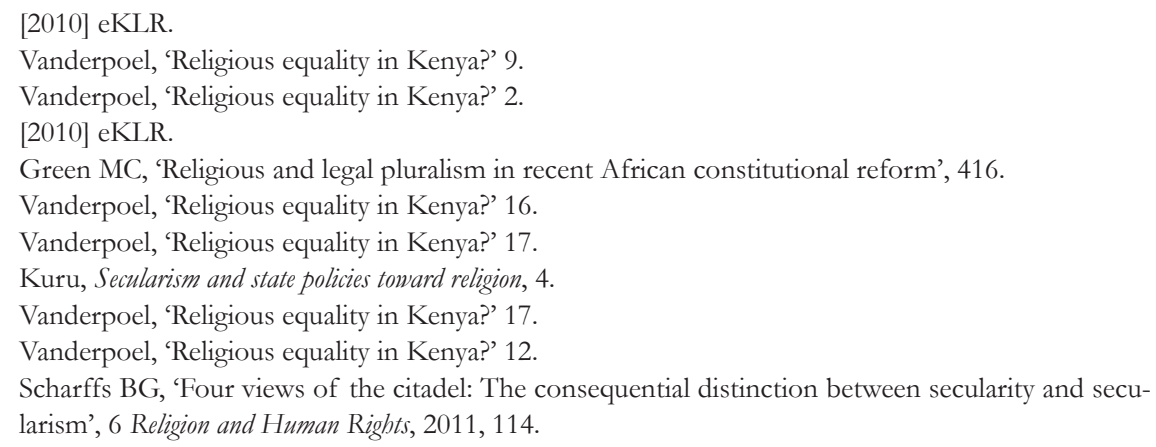


taining and protecting a secular order. ${ }^{68}$ The French position of laicité is seen as closer to secularism. On the other hand, the US separation of church and State under the establishment clause ${ }^{69}$ is more typical of secularity. In both contexts, the principal question remains how strictly secular the state should be. ${ }^{70}$

The danger with a strict secularist approach that tries to impose rather than promote consensus is evident in the far-field restrictions on religious symbols in education in France and Turkey. ${ }^{71}$ In France, the ban on religious symbols prohibits headscarves, 'large' Christian crosses, Sikh turbans and Jewish kippas. ${ }^{72}$ In a similar but more extreme vein, Turkey had strictly banned the wearing of headscarves in all public and private education institutions. ${ }^{73}$ The type of secularism that prohibits religious symbols to this extent begins to look like a 'breed of dystopian fundamentalism'. ${ }^{74}$ In this way, secularism may encourage what it seeks not be, that is, hostile, fearful of others and an enemy of alternative belief systems. ${ }^{75}$

According to Fugicha, Kenya favours a brand of neutrality that accommodates a broad range religions and beliefs. ${ }^{76}$ Put side by side with the French and Turkish experiences, the Kenyan position clearly does not promote a strict secular order. Coupled with the 2010 Constitution's provisions protecting religious freedom, accommodation emerges as the prevailing theme in Kenya's debate. The Court of Appeal in Fugicha appears to be positioning itself to advance discovery of shared values amidst difference. ${ }^{77}$

In Kenya High ${ }^{78}$ the judge equated tolerance of religion to secularism rather than secularity by sifting out and eliminating difference. The Fugicha court points

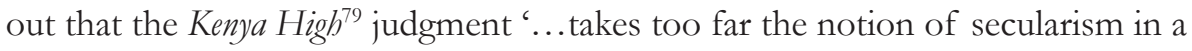
manner suggestive of hostility to religion... ${ }^{80}$ On the other hand, in Fugicha, ${ }^{81}$ a balance is struck between an individual's right to religious freedom and the State's

Scharffs, 'Four views of the citadel', 110-111.

69 Amendment I [1791], Constitution of the United States. 'Congress shall make no law respecting an establishment of religion, or prohibiting the free exercise thereof'.

70 Scharffs, 'Four views of the citadel', 111.

${ }^{71}$ Scharffs, 'Four views of the citadel', 121.

72 Kuru, Secularism and state policies toward religion, 106.

73 Kuru, Secularism and state policies toward religion, 164.

74 Scharffs, 'Four views of the citadel', 109.

75 Scharffs, 'Four views of the citadel, 126.

76 [2016] eKLR.

77 Calo, 'Pluralism, secularism and the European Court of Human Rights', 278.

78 [2012] eKLR.

79 [2012] eKLR.

80 [2016] eKLR.

81 [2016] eKLR. 
secularity by creating an environment for plurality, or difference, to be expressed and manifested.

Judges have the twin responsibility of determining a position from amongst the competing conceptions of religious freedom and preserving a community in peace. ${ }^{82}$ If judges keep in mind their power to either kill certain conceptions of religious freedom and to prescribe one 'official' conception they can avoid positing a view that goes contrary to the State's constitutional decrees on secularism. ${ }^{83}$ It is true that engaging in a comparative constitutional exercise can assist judges by highlighting the extent to which the legal system has developed in the area. ${ }^{84}$

It has been noted extensively that the tension present in multi-religious societies is 'one of the unavoidable consequences of pluralism'. ${ }^{85}$ How then can authorities ensure that competing groups tolerate each other?

In Kenya's case, the Fugicha judgment proposes a remedy that the Ministry of Education formulate regulations to guide schools and other educational institutions on how to better protect Article 32's right to freedom of religion and belief and uphold equality and freedom from discrimination under Article $27 .{ }^{86}$ The Court of Appeal acknowledges that any such regulations would only be general and thus schools should be responsible for formulating their own specific rules at the individual level, allowing for their unique circumstances and diversities to be appropriately addressed. Interestingly, this suggests that in theory, schools can adopt justified school uniform policies with differing accommodations for practice or manifestation of a religion or belief. Despite this, Fugicha posits that a policy that falls in line with the 2010 Constitution is accommodative of Muslim religious dress. To be a useful guide, the regulations would have to set clear parameters for schools to operate within.

The wider debate on meaning of secularism in Kenya can be taken to be a stock of tensions that exist between different religions in the country. A Pew Centre study ${ }^{87}$ reports that although distinct from the level of tensions in deeply divided religious societies in Africa such as Nigeria and the former Sudan, perceptions remain that Kenyan Muslims are subjected to unfair treatment when

\footnotetext{
Scharffs, 'Four views of the citadel', 124.

Scharffs, 'Four views of the citadel', 124.

4 Legarre S, 'Towards a new justificatory theory of comparative constitutional law', 1 Strathmore Law Journal (2015), 105.

Serif v Greece [2001] 31 EHRR 20.

[2016] eKLR.

Pew Forum on Religion and Public Life, Tolerance and tension: Islam and Christianity in sub-sabaran Africa.
} 
compared with the larger Christian majority. ${ }^{88}$ Nevertheless, there is no doubt that recent gains such as the embracing of Kadhis' courts in the 2010 Constitution and the Fugich $a^{89}$ judgment are positive signs of religious pluralism in the country. ${ }^{90}$ High expectations of religious freedom persist amidst 'the sunshine of liberty and freedom' afforded by 2010 Constitution. ${ }^{91}$

88 Green, 'Religious and legal pluralism in recent African constitutional reform', 432-433.

89 [2016] eKLR.

90 Green, 'Religious and legal pluralism in recent African constitutional reform', 439.

91 Fugicha [2016] eKLR. 